\title{
Synthesis of Isopalhinine A and Palhinine D
}

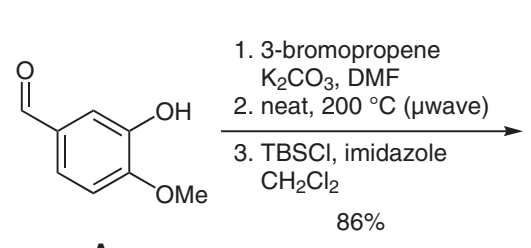

A

Claisen rearrangement<smiles>C=CCc1c(C=O)ccc(OC)c1OC</smiles>

B

\begin{tabular}{l} 
1. $\mathrm{MeCN}, t$-BuOK \\
$\mathrm{THF},-30{ }^{\circ} \mathrm{C}$ \\
2. $\mathrm{LAH}, \mathrm{THF}, 0^{\circ} \mathrm{C}$ to r.t. \\
\hline 3. $\mathrm{Boc}_{2} \mathrm{O}, \mathrm{EtOH}, 40^{\circ} \mathrm{C}$ \\
4. $\mathrm{TBSCl}_{\text {imidazole }}$ \\
$\mathrm{CH}_{2} \mathrm{Cl}_{2}$
\end{tabular}

$62 \%$

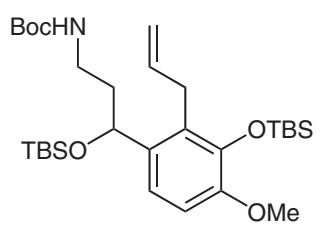

C

1. $\mathrm{BH}_{3} \cdot \mathrm{THF}, \mathrm{THF}, \mathrm{O}^{\circ} \mathrm{C}$ to r.t. then $\mathrm{NaOH}, \mathrm{H}_{2} \mathrm{O}_{2}, \mathrm{H}_{2} \mathrm{O}, 0^{\circ} \mathrm{C} \quad 86 \%$ 2. $\mathrm{MsCl}$, py, $0^{\circ} \mathrm{C}$ to r.t. $86 \%$

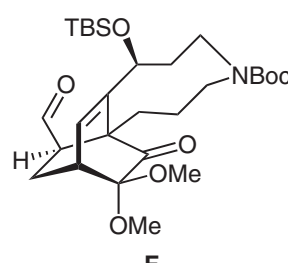
$\mathrm{Phl}(\mathrm{OAc})_{2}$ $\mathrm{MeOH}-\mathrm{CH}_{2} \mathrm{Cl}_{2}(1: 1)$ then acrolein, $\mathrm{PhMe}, \Delta$ 73\% $+22 \%$ epi-F oxidative dearomatization / Diels-Alder reaction<smiles>COc1ccc(C(CCN(CCCNC(=O)OCc2ccccc2)OC(C)(C)C)OC(C)(C)C)c(CCCC(=O)O)c1O</smiles>
$E$

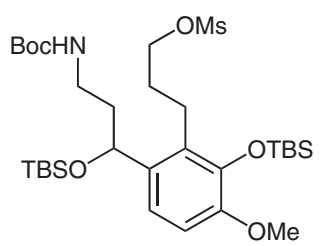

D

$$
\begin{array}{c|l}
88 \% & \begin{array}{l}
\text { 1. } \mathrm{G}, t-\mathrm{BuOK} \\
\mathrm{THF}, 0^{\circ} \mathrm{C} \text { to r.t. } \\
E / Z=2: 1
\end{array} \mid \begin{array}{l}
\text { 2. } \mathrm{Sml}, \mathrm{THF}-\mathrm{MeOH}(190: 1) \\
0^{\circ} \mathrm{C} \text { to r.t. }
\end{array}
\end{array}
$$

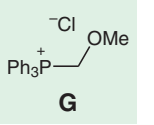

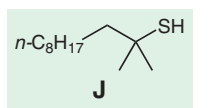

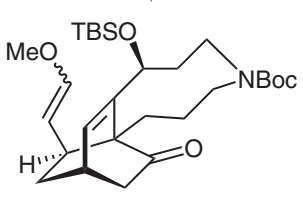

$\mathrm{H}$

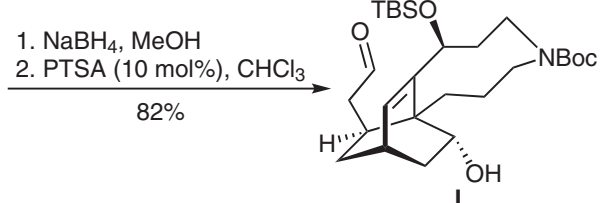

I

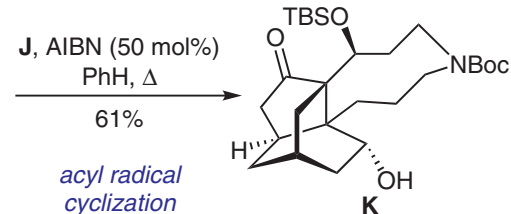

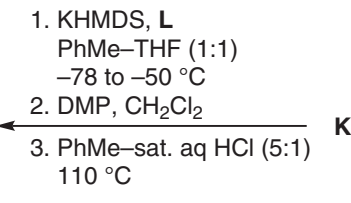

$19 \%$

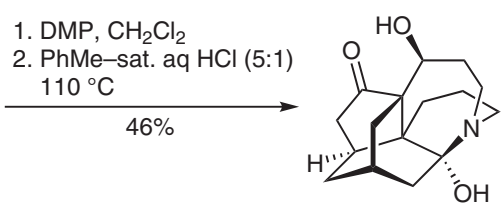

(ะ)-Palhinine D

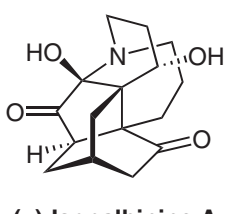

(土)-Isopalhinine A
Significance: Isopalhinine A and palhinine D are Lycopodium alkaloids with highly bridged carbon frameworks that incorporate a 5/6/6 tricycle along with a hemiaminal moiety. Hsieh and co-workers report concise syntheses of both alkaloids, which rely on an oxidative dearomatization/[4+2] cycloaddition strategy to construct the bicyclo[2.2.2]octane core.
Comment: 9-exo-Tet cyclization of $\mathbf{D}$ under basic conditions furnished the azonane ring in E. Subsequent oxidation with hypervalent iodine gave a masked ortho-benzoquinone intermediate that underwent Diels-Alder reaction with acrolein to afford F. Employing Tomioka's method, acyl radical cyclization of aldehyde I furnished the characteristic isotwistane core in $\mathbf{K}$. 